is reduced throughout most of its extent to an ependymal layer. Small localized thickenings may occur but nothing corresponding to the normal animal.

The difference in size and structure between the thyroid of an albino and that of a check is very marked. The thyroid of a normal 38 $\mathrm{mm}$. tadpole with $4.0 \mathrm{~mm}$. hind legs is approximately three times the size of a $37 \mathrm{~mm}$. albino with $0.1 \mathrm{~mm}$. hind legs. The compactness and character of the parenchyma show an even more striking contrast. A sagittal section through the thyroid of a $38 \mathrm{~mm}$. check shows on an average 15-18 vesicles, many of which are largely distended with colloid, the parenchyma of the whole gland being compacted together, as compared with that through the thyroid of a hypophysectomized $37 \mathrm{~mm}$. specimen which shows 4-5 atrophied vesicles containing but a slight amount, or no colloid, and with large spaces between the vesicles. The cells making up the vesicles of the former are cuboidal and protoplasmic-rich, in the latter little but nuclei remain. The results obtained from the experimental feeding of thyroid by Gudernatsch and others makes it highly probable that the non-development of the hind legs in the albinos is due immediately to the atrophy of the thyroid and not to the direct action of the hypophysis, a suggestion which Adler's work upon the tadpole also supports.

An examination of the gonads shows significant size differences between the normal and albino specimens. In the hypophysectomized animal the development of the sex glands is apparently much retarded and the size correspondingly reduced.

The author in a later and more complete account will describe any changes which may be found in the other endocrine glands and treat of the progressiveness of the changes noted.

P. E. Sмiтн

ANatomical Laboratory, UNIVERSITY OF CALIFORNIA

\section{EFFECT OF GRINDING SOIL ON THE NUMBER OF MICROORGANISMS}

IN connection with a study of the bacterial content of soil, it was found that pulverizing soil in a ball mill seriously affected the num- ber of bacteria. This treatment not only reduced greatly the bacteria, but also that of many other microorganisms. In many cases the soil was partially air dry and contained clumps which were not easily broken by shaking in a water suspension. Because of the mass of soil particles, it was thought that perhaps grinding would result in a higher count. From the results below, it will be seen that such was not the case. Instead of a gain, there was a loss in number of organisms which was more marked the longer the soil was ground.

The test was made as follows: Fresh or partially air-dried soil, containing not more than 10 per cent. moisture, was placed in a ball mill partly filled with large pebbles. The mill was geared so that the porcelain jar revolved at the rate of 70 revolutions per minute.

TABLE I

A COMPARISON OF THE NUMBER OF BACTERIA IN GROUND AND UNGROUND SOIL

\begin{tabular}{|c|c|c|c|c|c|}
\hline \multirow{2}{*}{ 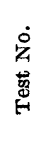 } & \multirow[b]{2}{*}{ Date } & \multirow[b]{2}{*}{ Soll } & \multicolumn{3}{|c|}{ Bacteria in One Gram of Dry Soll } \\
\hline & & & Unground & Ground & $\begin{array}{l}\text { Time of } \\
\text { Grind- } \\
\text { ing, } \\
\text { Hours }\end{array}$ \\
\hline 1 & April $\cdot 4$ & $\begin{array}{l}\text { Miami silt } \\
\text { loam }\end{array}$ & $4,225,000$ & $3,439,000$ & 1 \\
\hline 2 & April 5 & Red clay & 626,000 & 570,000 & 1 \\
\hline 3 & April 6 & Fine sand & 216,000 & 198,000 & 1 \\
\hline 4 & April 11 & $\begin{array}{c}\text { Black silt } \\
\text { clay loam }\end{array}$ & $3,300,000$ & $2,200,000$ & 1 \\
\hline 5 & April 12 & $\begin{array}{l}\text { Colby silt } \\
\text { loam }\end{array}$ & $1,200,000$ & $1,800,000$ & 1 \\
\hline 6 & April 13 & $\begin{array}{c}\text { Carrington } \\
\text { silt loam }\end{array}$ & $2,000,000$ & 400,000 & 1 \\
\hline 7 & April 14 & Sandy loam & $1,200,000$ & 300,000 & 1 \\
\hline 8 & April 18 & $\begin{array}{l}\text { Medium } \\
\text { sand }\end{array}$ & 362,000 & 186,000 & 1 \\
\hline 9 & April 19 & $\begin{array}{l}\text { Plainfield } \\
\text { loam }\end{array}$ & 264,000 & 174,000 & 1 \\
\hline 10 & April 20 & Muck & $2,064,000$ & $1,746,000$ & 1 \\
\hline 11 & April 26 & $\begin{array}{l}\text { Miami silt } \\
\text { loam }\end{array}$ & $44,602,000$ & 10,540 & 8 \\
\hline 12 & May & Garden soil & $3,194,000$ & 5,610 & 8 \\
\hline 13 & May & Garden soil & $3,194,000$ & 75 & 24 \\
\hline
\end{tabular}

The following results, shown in Table I., illustrate the difference in the number of bacteria in the ground and the unground soil, as well as the effect of time of grinding on the number of bacteria. Grinding greatly reduced the number of bacteria except in one case, No. 
5 Colby silt loam. Apparently the greatest injury caused by grinding for one hour is noted in the case of sandy soils.

When the soils were ground for 8 or 24 hours, there was an enormous decrease in the bacterial flora. This is readily noted from the figures of the last three soils given in Table I. After 24 hours of grinding the soil was rendered almost free of bacteria.

It is of interest in this connection to note the effect of long grinding on other soil organisms, e. g., soil protozoa. Dilution counts on various culture solutions adapted to protozoa showed that the unground soils contained protozoa in dilutions greater than 1 to 10,000 , while in many cases the ground soil failed to show any growth of protozoa. The garden soil, No. 12, contained protozoa in the first dilution, one gram in 10 c.c. of the medium. When ground for 24 hours this same soil did not show the presence of protozoa.

From the results, it seems fair to conclude that grinding soil in a ball mill injures the soil microorganisms. If this process is continued for several hours, the soil will be partially sterilized. Although no definite study has been made, it is most probable that the larger forms of plant life as fungi, yeasts and algæ suffer the same fate as the protozoa and bacteria.

\section{UNIVERSITY OF WISCONSIN}

$$
\text { E. B. Fred }
$$

\section{AN ACOUSTIC DEMONSTRATION BEARING ON THE PULSE THEORY OF RADIATION}

Some years ago I made the acquaintance of the "pulse theory" of radiation. As I understood it then, the periodicity of any monochromatic light as observed by means of a spectral system was a function of the instrument of dispersion. If so, how various sources could give different spectra when their radiation was dispersed by the identical instrument was to me an unanswered question. It was unthinkable that there should not be some characteristic difference between the pulses, or their manner of succession, in the two cases.

The demonstration which I am about to describe developed as the result of a more recent informal discussion of the subject in this laboratory. 'It occurred to me that the acoustic analogy of such a theory should have as its consequence this fact: that an irregular series of impacts would cause wave disturbances in the air such that a resonator of any period, within certain limits, should respond.

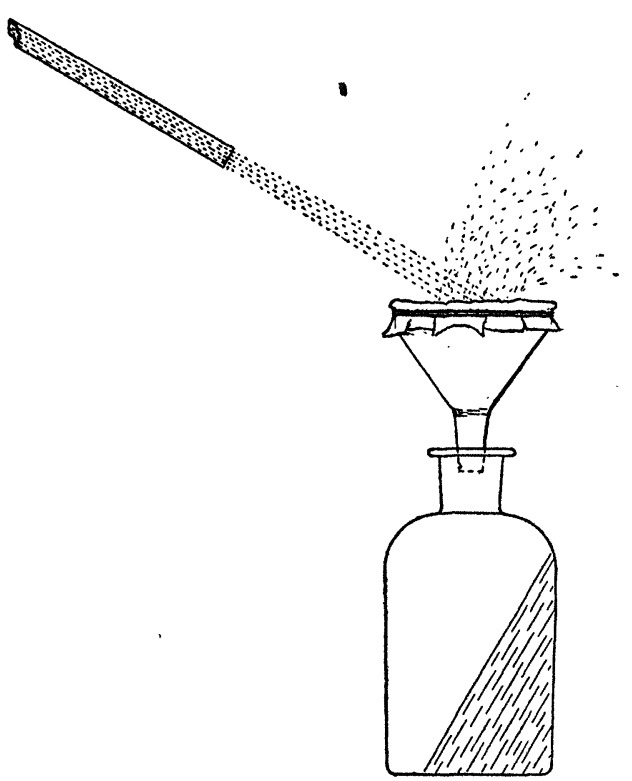

Fig. 1.

Such a series of impacts was furnished by a stream of sand-particles falling against an inclined paper surface, and the resonator was the classic glass bottle, which was made to respond to different periods by introducing different amounts of water.

Essentially the experimental set-up (which was about twenty minutes in construction) consists of a vertical glass tube of $7 \mathrm{~mm}$. bore, constricted to about $4 \mathrm{~mm}$. at a point near its top and some $42 \mathrm{~cm}$. from its lower end; of a funnel, whose expanded end is covered with a rather loose diaphragm of thin tracing paper; and the resonator described. The sand was allowed to flow through the constriction in the tube, and the stream subsequent to this was kept from spreading too much by the portion of the tube below, falling freely a distance of $12 \mathrm{~cm}$. from the lower extremity of the latter before striking the diaphragm (Fig. 1). The sand was what is known to the drug trade as 